\title{
ALLELOPATHIC EFFECTS OF PATHOGENIC FUNGI ON WEED PLANTS OF SOYBEAN AND CORN CROPS
}

\author{
ALELOPATIA DE FUNGOS FITOPATOGENNICOS SOBRE PLANTAS INVASORAS \\ DA CULTURA DA SOJA E MILHO
}

\begin{abstract}
Ariane SPIASSI ${ }^{1}$; Lúcia Helena Pereira NÓBREGA ${ }^{2}$; Danielle Medina ROSA ${ }^{3}$; Fábio Palczewski PACHECO ${ }^{4}$; Jaqueline SENEM ${ }^{5}$; Gislaine PICCOLO DE LIMA ${ }^{3}$

1. Bióloga, Doutoranda, Programa de Pós-Graduação em Engenharia Agrícola - PGEAGRI, Universidade Estadual do Oeste do Paraná UNIOESTE, Cascavel, PR, Brasil. arispiassi@ hotmail.com; 2. Engenheira Agrônoma; Doutora, Professora Associada, PGEAGRI, UNIOESTE, Cascavel, PR, Brasil; 3 Bióloga, Pós-Doutoranda, Universidade Estadual do Oeste do Paraná - UNIOESTE, Cascavel, PR, Brasil; 4. Engenheiro Agrícola, Doutorando, PGEAGRI, UNIOESTE, Cascavel, PR, Brasil; 5. Bióloga, Mestre, PGEAGRI, UNIOESTE, Cascavel, PR, Brasil.
\end{abstract}

\begin{abstract}
The herbicides application can be reduced with alternative methods, as pathogenic fungi use, that produces several secondary compounds in growth medium, which has phytotoxicity. Thus, the aim of this study was to determine the allelopathic activity of culture filtrate produced by pathogenic fungi: Fusarium solani, Macrophomina phaseolina Fusarium graminearum and Diplodia maydis, on germination and development of horseweed (Conyza canadensis), hairy beggarticks (Bidens pilosa) and wild poinsettia (Euphorbia heterophylla). This effect was also tested on soybean and corn crops. The experimental design was completely randomized with twenty treatments (four filtrates of fungi culture, with $0,5,10,15$ e $20 \%$ concentrations) and four replications. Data were submitted to analysis of variance and regression. The results indicated that filtered of Fusarium solani culture presented a negative effect on horseweed, hairy beggarticks and wild poinsettia without affecting negatively soybeans crop. Diplodia maydis provided some reduction on horseweed and wild poinsettia growth without causing damage to maize crop.The while Macrophomina phaseolina filtrate decreased a seedlings growth of wild poinsettia without affecting negatively corn. This suggests filtrates can be used to control weeds in a sustainable ecological way as well as an alternative to reduce herbicides application, thus, protecting the environment.
\end{abstract}

KEYWORDS: Alternative control. Allelochemicals. Fungal filtrate. Fusarium solani.

\section{INTRODUCTION}

The weed control is important to obtain high yields on farming and it is as old as the agriculture itself. In order to reach greater yield and soil conservation, correct procedures in crop management, weed control carries as a great alternative since weeds, which is continually compete for water, light and nutrients and reduces crops yield concern higher the production cost consequently, there is which also interferes in harvest and mix the seeds with the crop, reducing quality (COSTA, 1996).

The herbicides integration in agricultural market has gradually increased so, it indiscriminate use contaminates the environment with serious consequences to everyone. It also leads to development of many reports concerning weeds resistance, which is a consequence in most cases of mutations or pre-existence of genes that confer resistance to the population (RIZZARDI et al., 2002; AGOSTINETTO; VARGAS, 2009).

Traditionally, these weeds control has been carried out with herbicides application, which in short-term, show advantages, but it can cause problems in long-term due to its pollutant residues in soil. As a result, it is necessary to develop alternative control methods, which besides, can reduce some negative environmental impacts and are cheaper than chemical control.

Paraná has $80 \%$ of its territory occupied by agricultural yield and uses $12 \mathrm{~kg}$ pesticides per hectare per year, while the Brazilian regions consume the third part of this $\left(4 \mathrm{~kg} \mathrm{ha}^{-1} \mathrm{yr}^{-1}\right)$. Among these pesticides, $60 \%$ are herbicides and Cascavel consume the most amount $\left(23 \mathrm{~kg} \mathrm{ha}^{-1} \mathrm{yr}^{-1}\right)$ when compare to, Londrina (21 kg ha $\left.{ }^{-1} \mathrm{yr}^{-1}\right)$ and Ponta Grossa $\left(20 \mathrm{~kg} \mathrm{ha}^{-1} \mathrm{yr}^{-1}\right)$ (IPARDES, online, 2010).

The practice of such alternative control does not use pesticides, although they may be associated in an integrated manner to traditional methods of chemical control and/or cultural practices in order to increase their efficiency (MORAES, 1992).

The allelochemicals activity has been used as an alternative to the use of herbicides, insecticides and nematicides (pesticides). Most of these substances come from the secondary metabolism, since in plants evolution they shown some advantage against microorganisms, viruses, 
insects and other pathogens or predators activities, either inhibiting their action or stimulating plants growth or development (WALLER et al., 1999). And among phytopathogenic fungi produce toxins that attack soybean ( $F$. solani, Sclerotium rolfsii) and maize (Penicillium oxalicum; Exserohilum turcicum) crops.

The allelochemicals may interfere on the several metabolism plants in various ways, such as plant growth regulators, photosynthesis inhibitors, disrupters of respiration and transport into cell membrane and inhibitor of enzymatic and protein activity (EINHELLIG, 1986). According to Weih et al. (2008), it is emphasized the possibility of using allelopathic activity as an alternative to the chemical control application for weed plants suppression in agroecosystems.

The toxins effect present in the culture filtrate of $F$. solani was evaluated from 1 to $4 \%$ concentrations on seed germination and radicle and hypocotyl development of malice (Mimosa pudica L.) and "mata-pasto" (Senna obstusifolia L.). The results showed allelopathic activity with stronger inhibitory effect at 4\% concentration (SOUZA FILHO; DUARTE, 2007).

In this context, the aim of this study was to evaluate the allelopathic activity of culture filtrates produced by pathogenic fungi that attack soybean ( $F$. solani and $M$. phaseolina) and maize ( $F$. graminearum and $D$. maydis) on weed plants of these crops.

\section{MATERIAL AND METHODS}

The experiment was carried out at the Lab of Seeds and Plants Evaluation (LESP) at the Center for Science and Technology, Campus of Cascavel, Western Paraná State University - UNIOESTE.

Fungi strains were placed in Petri dishes with Potato Dextrose Agar (PDA) growth medium and monitored for seven days at $25^{\circ} \mathrm{C}$. After this period, three disks with $10 \mathrm{~mm}$ diameter were taken from the colonies edges and transferred aseptically to $250 \mathrm{~mL}$ flasks. Each erlenmeyer contained $100 \mathrm{~mL}$ dextrose potato broth liquid medium (BD) previously sterilized by autoclaving at $120^{\circ} \mathrm{C}$, and 1 atm during $20 \mathrm{~min}$, as described by Souza Filho and Duarte (2007).

Aiming at stimulating the toxin production, the flasks were kept under stirring $(150 \mathrm{rpm})$ at $26^{\circ}$ $\mathrm{C}$, room light (laboratory) during 20 days incubation. The cultures were double filtered on double gauze for mycelium removal, and then sterilized through a Millipore membrane $(0.45 \mu \mathrm{m})$, with a filter system under vacuum for spores removal (crude culture filtrate). This methodology was adapted from Duarte and Archer (2003) and Viecelli et al. (2009).

In order to verify the interference of phytopathogenic fungi culture filtrates on seed germination and the early seedlings development of wild poinsettia, horseweed and hairy beggartics was performed the allelopathic activity in the laboratory. The tests were performed by diluting the crude filtrate with $0,5,10,15$ and $20 \%$ concentrations. The control treatment contained only distilled water.

The substrate for sowing was germination paper in gearboxes, dampened in two and a half times ratio the paper mass in water volume (control) or culture filtrates of phytopathogenic fungi. The solution was added once at the beginning of the bioassay, and up from then, only distilled water was added when necessary. The germination boxes were placed in BOD-type oven.

The seeds remained at $27^{\circ} \mathrm{C}$ under $12 \mathrm{~h}$ photoperiod, the counting were performed daily until the $11^{\text {th }}$ day of germination for wild poinsettia (adapted from BRASIL, 2009), from the $1^{\text {st }}$ to $30^{\text {th }}$ day of germination for horseweed (adapted from LAZAROTO et al., 2008) and from the $1^{\text {st }}$ to $15^{\text {th }}$ day of germination for hairy beggarticks (adapted from CARMONA; VILLAS BÖAS, 2001).

The count of germinated seeds was carried out after the first day of radicle emergence, until stabilization of the seedlings number, according to Nakagawa (1999) method. Seeds that showed radicle protrusion were considered germinated (BEWLEY; BLACK, 1994). The SGI was calculated according to Maguire (1962).

Data used to evaluate the germination speed (SG) were the same used for germination speed index (SGI) evaluation. The SG was calculated according to Edmond and Drapala (1958), who consider that the treatment with the lowest mean took less days prior to the seeds germination, so it was the one with the highest germination rate.

After the growth period, as described above, the primary root length $(\mathrm{cm})$ and hypocotyls length $(\mathrm{cm})$ of five normal seedlings per replication were determined, and these measurements were performed with graduated scale (accuracy of 1.0 $\mathrm{mm})$. For horseweed seedlings the whole seedling length $(\mathrm{mm})$ was determined due to its small size using a digital caliper Zaas ${ }^{\circledR}$ Precision $(0.05 \mathrm{~mm}$ precision).

Subsequently it, the fresh mass of roots and shoots of wild poinsettia and fresh mass of the whole seedling for hairy beggarticks were determined. For dry mass, seedlings were placed in paper bags properly identified and taken to the oven 
at $60^{\circ} \mathrm{C}$ for $48 \mathrm{~h}$. The weighing was performed on a precision scale of $0.0001 \mathrm{~g}$, determining the total dry mass of five seedlings for each replication. The mass of horseweed was not determined due to its small size and fast dehydration.

In order to verify that if culture filtrates interfere on germination and early seedling development of soybean and maize (cultivated plants) seedlings, the allelopathic activity was tested in the laboratory using the soybean cultivar CD 215 from COODETEC and the hybrid maize 330 from Agroeste. Concentrations were the same used in the weeds.

The standard germination test was performed with four replications of 50 seeds for each treatment. Germination paper was moistened at twice water volume ration (control) or culture filtrates on the paper mass was used as substrate for sowing (MARCOS FILHO et al., 1987). The rolls were made of three paper sheets. Two of them were used as support for seeds distribution; one cover sheet and then they were placed in the germinator at $25^{\circ} \mathrm{C}$. Evaluations of seeds and seedlings were performed according to the Rules for Seed Analysis (BRASIL, 2009) criteria.

The primary root length $(\mathrm{cm})$ and shoot length $(\mathrm{cm})$ of 10 normal seedlings of each repetition, and fresh mass of roots and shoots were determined; afterwards, the plants were placed in paper bags properly identified and taken to the oven at $65^{\circ} \mathrm{C}$ during $48 \mathrm{~h}$. The weighing was performed with $0.0001 \mathrm{~g}$ precision scale, determining the total dry mass for each replication.

The experimental design was completely randomized. Data were submitted to analysis of variance (ANOVA) with the statistical software SISVAR (FERREIRA, 2000). The averages were compared by treatments and data were analyzed by the Skott-Knott test at 5\% probability. The variables were significantly affected by the treatments submitted to regression analysis at $5 \%$. At last, the culture filtrate concentration was considered independent variable.

\section{RESULTS AND DISCUSSION}

The parameters germination percentage and germination speed index showed no statistically significant difference for seeds of wild poinsettia treated with culture filtrates obtained from $F$. graminearum, F. solani, $M$. phaseolina and $D$. maydis. According to Ferreira and Borguetti (2004), germination is less sensitive to allelochemicals than seedling growth. The germination rate did not suffer negative effects of the culture filtrates. The $F$. graminearum and $F$. solani species anticipated seed germination when compared with the control at 5\% probability by the Skott-Knott test.

Different results were obtained by Magiero et al. (2009), whose peanuts germination was completely inhibited by the use of aqueous extract from Artemisia annua (erva-de-são-joão) plant at $75 \%$. These authors observed no significant reduction in the average germination speed of wild peanuts in treatments up to $20 \%$ concentration.

There were no similar studies using culture filtrates on the germination and early growth of wild poinsettia, which led to pursue studies using plant extracts as alternative to weed control.

The results for the regression analysis of the culture filtrate obtained from $F$. graminearum on the initial growth of wild poinsettia, which promoted smaller growth of roots and shoots, decreased fresh and dry mass of roots and shoots as there was an increase on culture filtrate concentration, since the determination coefficients (R2) were high (Figure 1).

The filtrate produced by $F$. solani showed regular coefficient of determination for root growth $\left(\mathrm{R}^{2}=0.81\right)$ and good for shoot growth $\left(\mathrm{R}^{2}=0.97\right)$ as well as fresh and dry mass of shoot $\left(\mathrm{R}^{2}=0.99\right)$ (BANZATTO; KRONKA, 1995). The variation of other characteristics is not explained by the increased culture filtrate concentration as shown in Figure 2.

The filtrate obtained from $M$. phaseolina decreased growth and dry mass of roots and shoots of wild poinsettia seedlings. It also showed regular coefficient of determination $\left(\mathrm{R}^{2}\right), 0.64,0.99$ and 0.88 , respectively (Figure 3 ).

The filtrate produced by $D$. maydis reduced the root growth and shoot dry mass of wild poinsettia seedlings showing regular coefficient of determination $\left(\mathrm{R}^{2}\right)$ 0.56. The variation in other characteristics was not consistent regarding the applied filtrate concentrations, obtaining coefficients of variation lower than 0.50 (Figure 4).

The experiment developed by Maller et al. (2010a) showed that the treatment with $100 \%$ aqueous extract of Titonia diversifolia (Mexican sunflower) showed the best potential for controlling wild poinsettia, since it affected the growth of hypocotyl and radicle of seedlings. Treatments 6,12 and $24 \mathrm{CH}$ (Hahnemannian Proximate), from extract dinamization, stimulated the growth of shoot and root and therefore, it cannot be used to control these weeds.

These results were similar to those ones obtained in the experiment using the culture filtrate of $F$. solani at lower concentrations (15 and 20\%), 
so, there is a greater efficiency in terms of concentration and economy of crude extract.
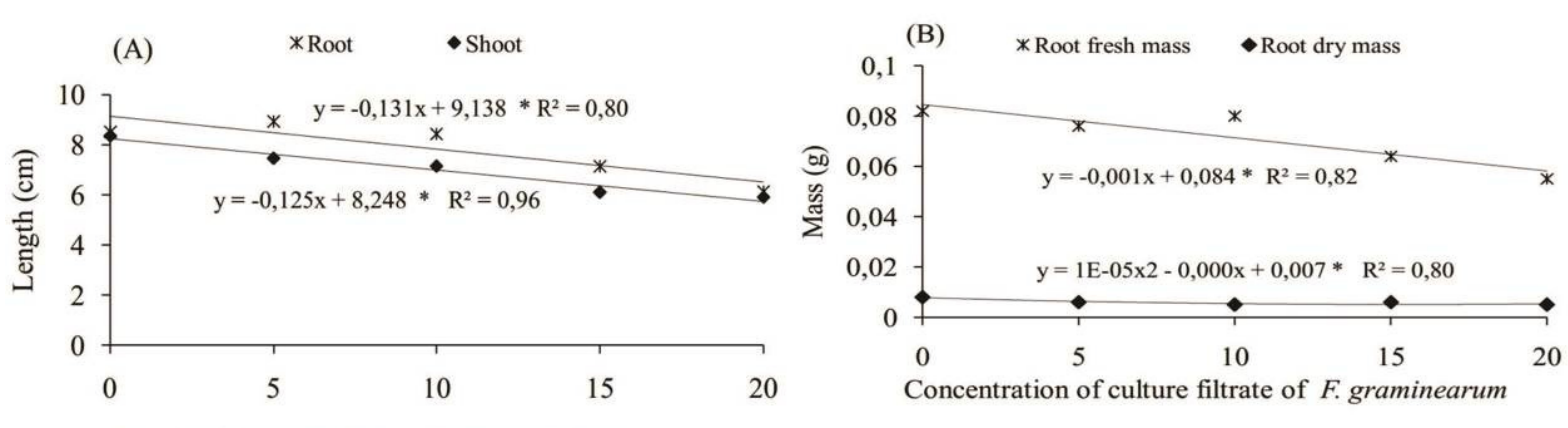

(C) * Fresh mass of shoot $\bullet$ Dry mass of shoots

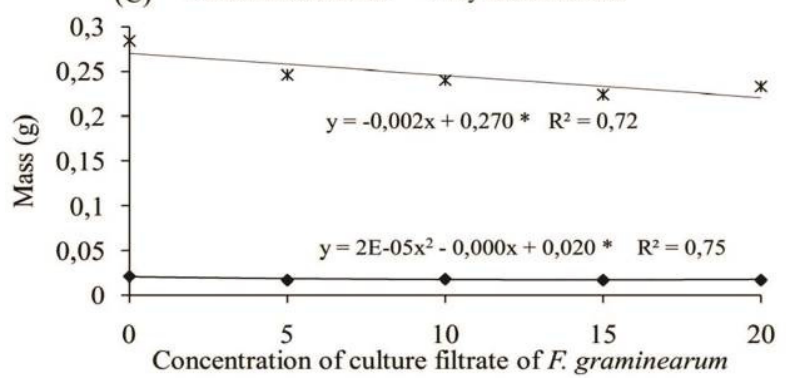

Figure 1. Seedling length (A), fresh and dry mass of root (B) and shoot (C) of wild poinsettia depending on the culture filtrate produced by Fusarium graminearum with concentrations ranging from 0 to $20 \%$. *: Significant $(\mathrm{p} \leq 0.05)$.
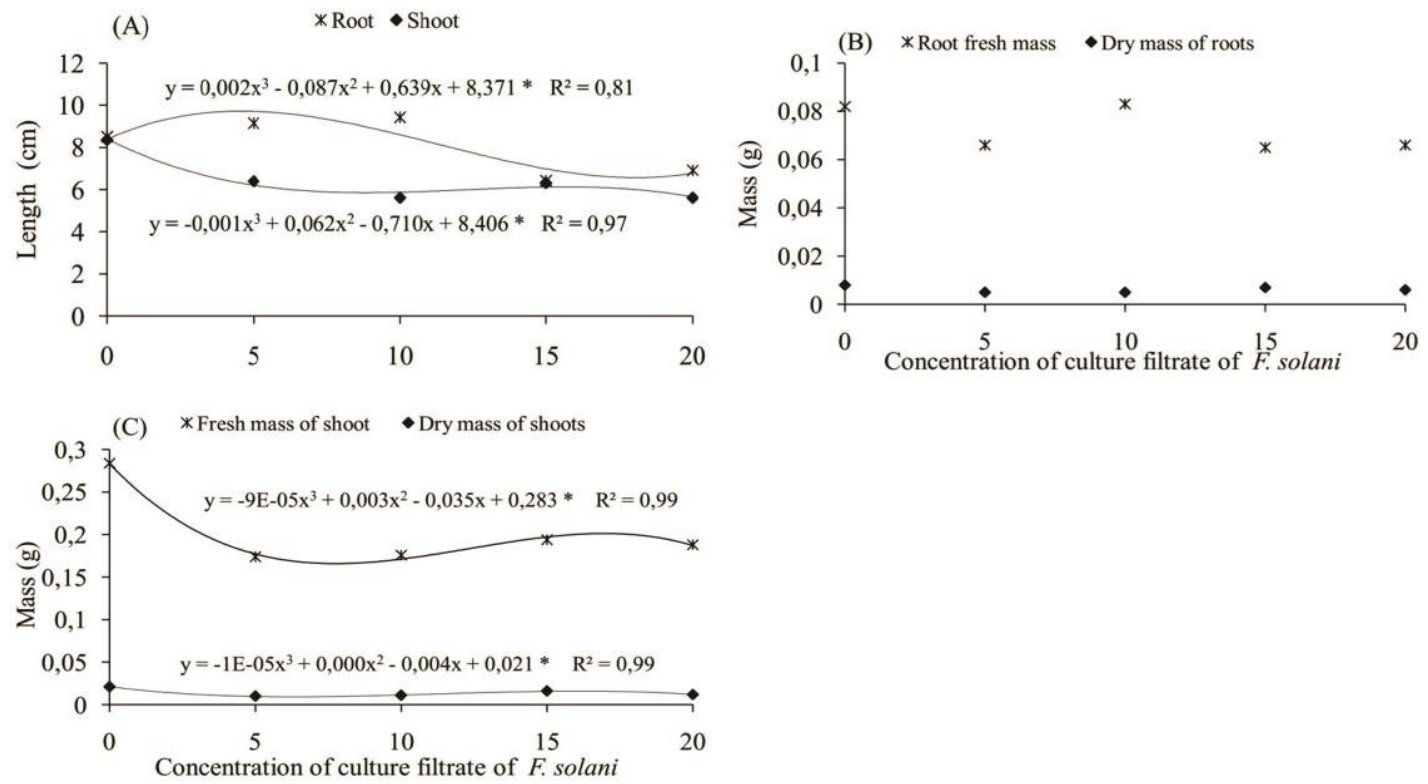

Figure 2. Seedling length (A), fresh and dry mass of root (B) and shoot (C) of wild poinsettia depending on the culture filtrate produced by Fusarium solani with concentrations ranging from 0 to $20 \%$. *: Significant $(\mathrm{p} \leq 0.05)$; Without curve: not significant. 

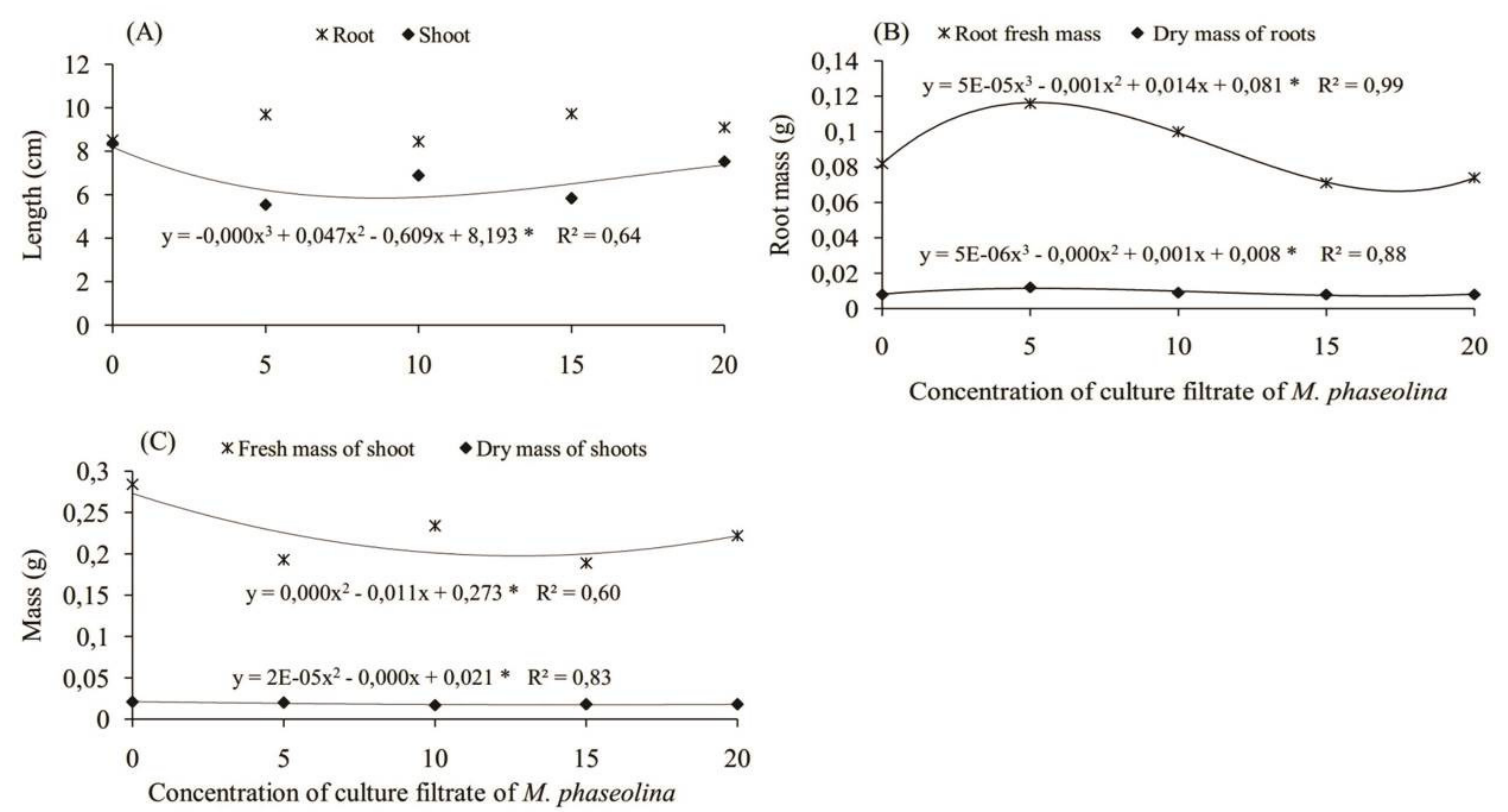

Figure 3. Seedling length (A), fresh and dry mass of root (B) and fresh and dry mass of shoot (C) of wild poinsettia depending on the culture filtrate produced by Macrophomina phaseolina with concentrations ranging from 0 to $20 \%$. *: Significant $(\mathrm{p} \leq 0.05)$; Without curve: not significant.
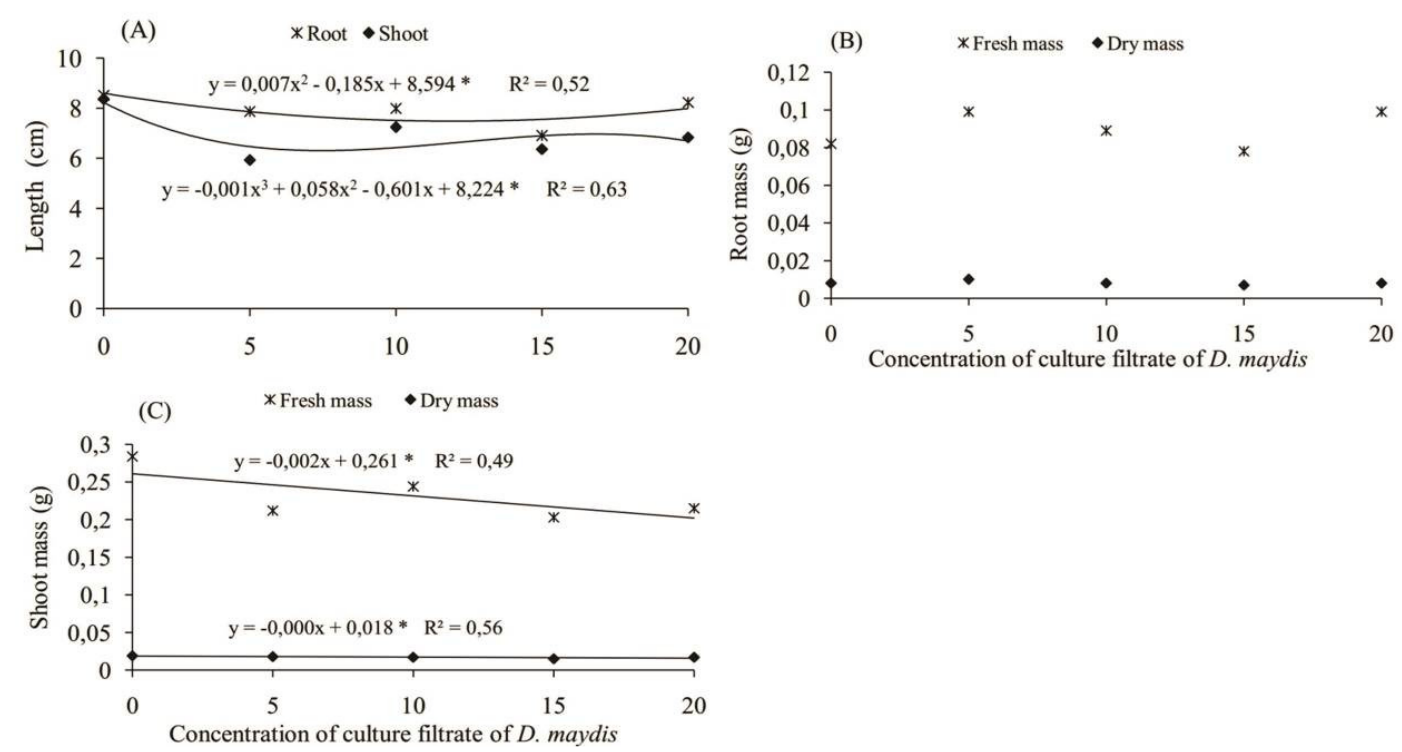

Figure 4. Seedling length (a), fresh and dry mass of root (b) and fresh and dry mass of shoot (c) of wild poinsettia depending on the culture filtrate produced by Diplodia maydis with concentrations ranging from 0 to $20 \%$. *: Significant $(\mathrm{p} \leq 0,05)$; Without curve: not significant.

Magiero et al. (2009) concluded that the aqueous extract from plants of Artemisia aпnиa L. (erva-de-são-joão) showed allelopathic effect on root growth of wild poinsettia seedlings, so, there was a significant reduction on root length at 25 and $50 \%$, and a complete inhibition at 75 and $100 \%$.

Souza et al. (1997) used extracts of three forage leguminous to develop three weed plants of pasture. The results showed that the root is a more sensitive indicator than germination to aqueous extracts, noting that this variable is an important ecological aspect, since root system inhibition would be determinant, as it would prevent normal development of plants affected by allelochemicals.

Thirty days after sowing, the average percentage of horseweed seeds germination showed no statistically significant difference among treatments. In the results obtained with the SGI, there were the lowest averages when using the treatments with the filtrates obtained from $D$. maydis (Figure 5c) and F. solani 20\% (Figure 5b). According to Ferreira and Borghetti (2004), often 
the allelopathic effect is not on the germination percentage, but on the germination speed, fact observed in this trial.

There are difficulties in finding similar works using culture filtrates or plant extracts as alternative control of horseweed plants. Therefore, as an example of chemical control of this plant, Oliveira Neto et al. (2010) evaluated the effectiveness of management strategies during the winter after the maize harvest, and summer management prior to soybean planting, on the horseweed control, using a mixture of glyphosate +2.4-D combined or not with residual herbicides. The authors found out that, in all management systems where the herbicide 2,4-D was associated with glyphosate, all weeds were controlled.

Since, there is a great difficulty in finding trial concerning alternative horseweed control, in which no pesticides are use, this trial should be highlighted.

The germination speed was negatively affected by filtrates of $F$. graminearum from $10 \%$ concentration (Figure 5a), F. solani at 15 to $20 \%$ (Figure $5 b$ ), and D. maidys (Figure 6c) from 5\% concentration. The higher the culture filtrates concentration the slower the germination of horseweed seeds.

Culture filtrates from $F$. graminearum, $F$. solani and D. maydis reduced the germination speed index, germination speed and horseweed seedlings length with high coefficients of determination $\left(\mathrm{R}^{2}\right.$ greater than 0.80) (BANZATTO; KRONKA, 1995) (Figure 5). It is observed that the filtrate of $M$. phaseolina showed no correlation in all evaluated parameters, therefore, there was no influence of the filtrate on horseweed species (Figure 5C).
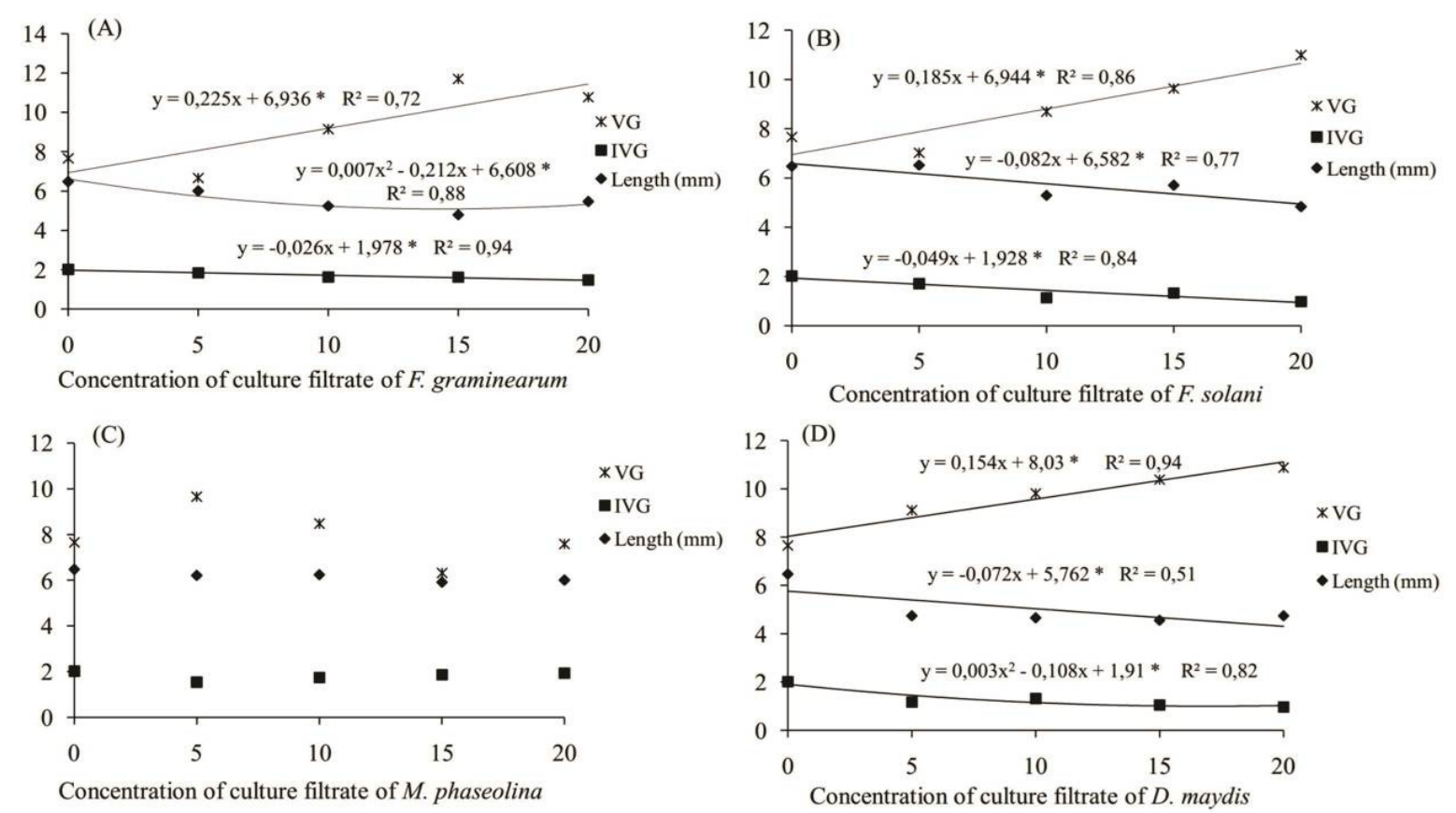

Figura 5. SG, SGI and seedlings length of horseweed according to the culture filtrate produced by Fusarium graminearum (A), Fusarium solani (B), Macrophomina phaseoalina (C), Diplodia maydis, (D) at concentrations ranging from 0 to 20\%. *: Significant ( $\mathrm{p} \leq 0.05$ ); Without curve: not significant.

Tested on the hairy beggarticks weed, the culture filtrate of $F$. graminearum inhibited the root growth, whose coefficient of determination $\left(\mathrm{R}^{2}\right)$ was 0.83 but it also stimulated shoots growth (Figure 6 A-2). The parameters showed weak coefficient of determination, so, this culture filtrate was not effective in controlling this weed (Figure 6 A-1 and 6 A-3).

The filtrate obtained from $F$. solani reduced the growth of roots and shoots (Figure 6 B-2) and fresh mass (Figure $6 \mathrm{~B}-3$ ), according to the increased concentration with high coefficients of determination $\left(\mathrm{R}^{2}\right.$ greater than 0.80$)$.

Souza Filho and Duarte (2007) obtained results that showed allelopathic activity, with more intense effect at $4 \%$ toxins they were present in the culture filtrate produced by $F$. solani on the seed germination and development of radicle and hypocotyl of malice (Mimosa pudica L.) and matapasto (Senna obstusifolia L.). It was also observed in this study the growth inhibition of hairy beggartticks when the filtrate of $F$. solani was applied. Thus, it can be stated that the filtrate of $F$. 
graminearum only decreased the root growth and the filtrate of $F$. solani reduced growth and fresh mass of hairy beggartticks.
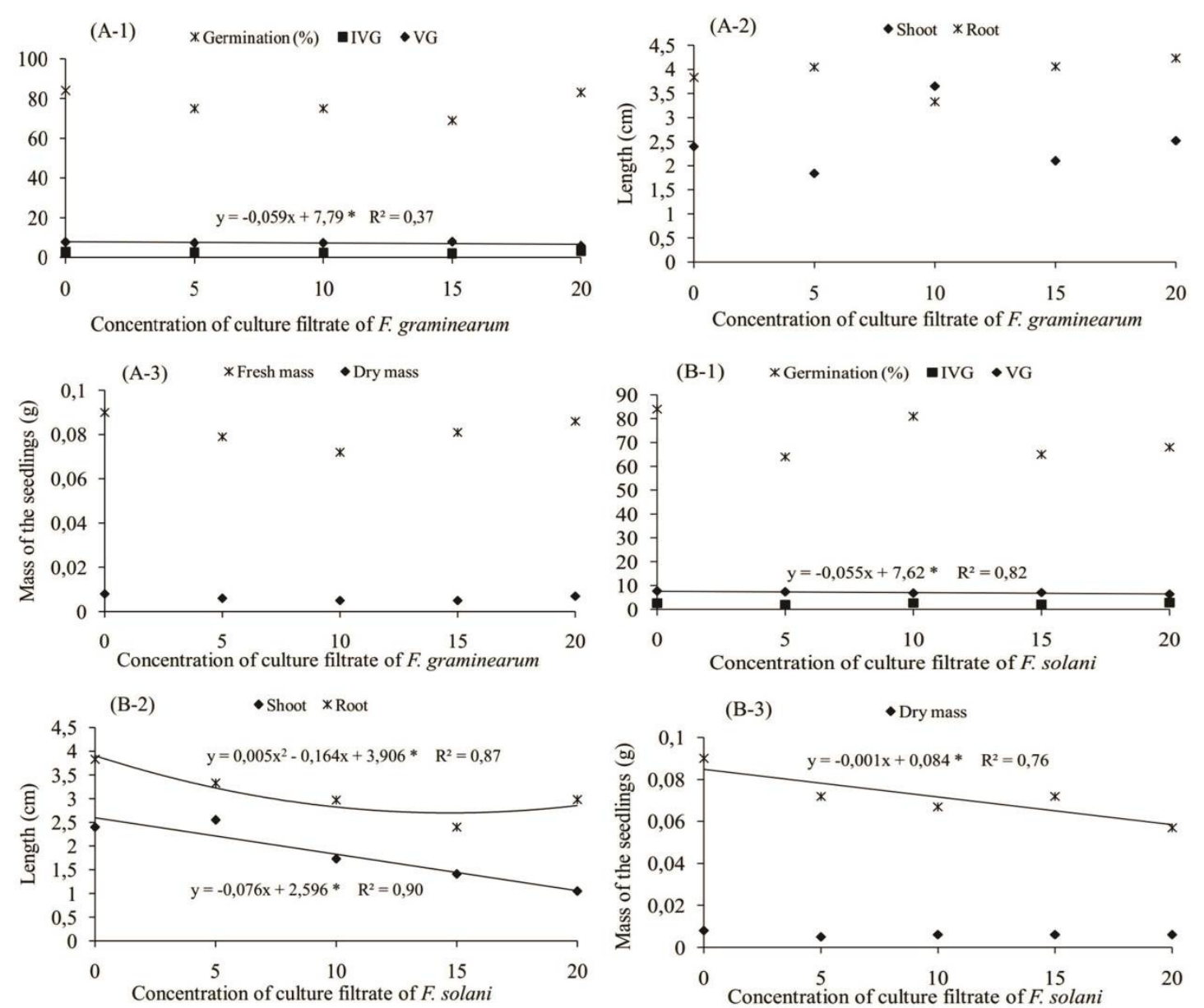

Figure 6. Germination percentage, SGI and SG (1), length (2) and mass (3) of hairy beggartticks depending on the culture filtrate produced by Fusarium graminearum (A), Fusarium solani (B) at concentrations ranging between 0 to $20 \%$. *: Significant $(\mathrm{p} \leq 0.05)$; Without curve: not significant.

The remaining filtrates led to increased averages of the variables analyzed, but this was not the objective of this study, which aimed at controling weeds (Figure 7).

Thus, it can be stated that the filtrate of $F$. graminearum only decreased the root growth and the filtrate of $F$. solani reduced growth and fresh mass of hairy beggartticks.

The soybean germination was not affected by the culture filtrates when compared with control. The culture filtrate of $F$. graminearum decrease roots length of soybean seedlings, as it concentration increase. The shoot suffered stimulatory effect (Figure 8A). The mass answer was not adversely affected by increasing the concentration (Figure $8 \mathrm{~B}$ ).

The other parameters showed low coefficient of determination and no negative interference of culture filtrates of $F$. solani (Figure 9A), M. phaseolina (Figure 9B) and D. maydis (Figure 9C) on the soybean. The germination percentage of maize seeds also showed no significant difference and the root length remained equal to or higher than the control. This indicates that the culture filtrates do not affect negatively germination and root length of this culture.

The concentrations of culture filtrates obtained from $F$. graminearum and $F$. solani reduced shoots growth in maize (Figure 10-A and 10-B) with high coefficients of determination. The culture filtrates, obtained from $M$. phaseolina (Figure 10-C) and D. maydis (Figure 10-D), showed no negative interference on the parameters evaluated in maize. 

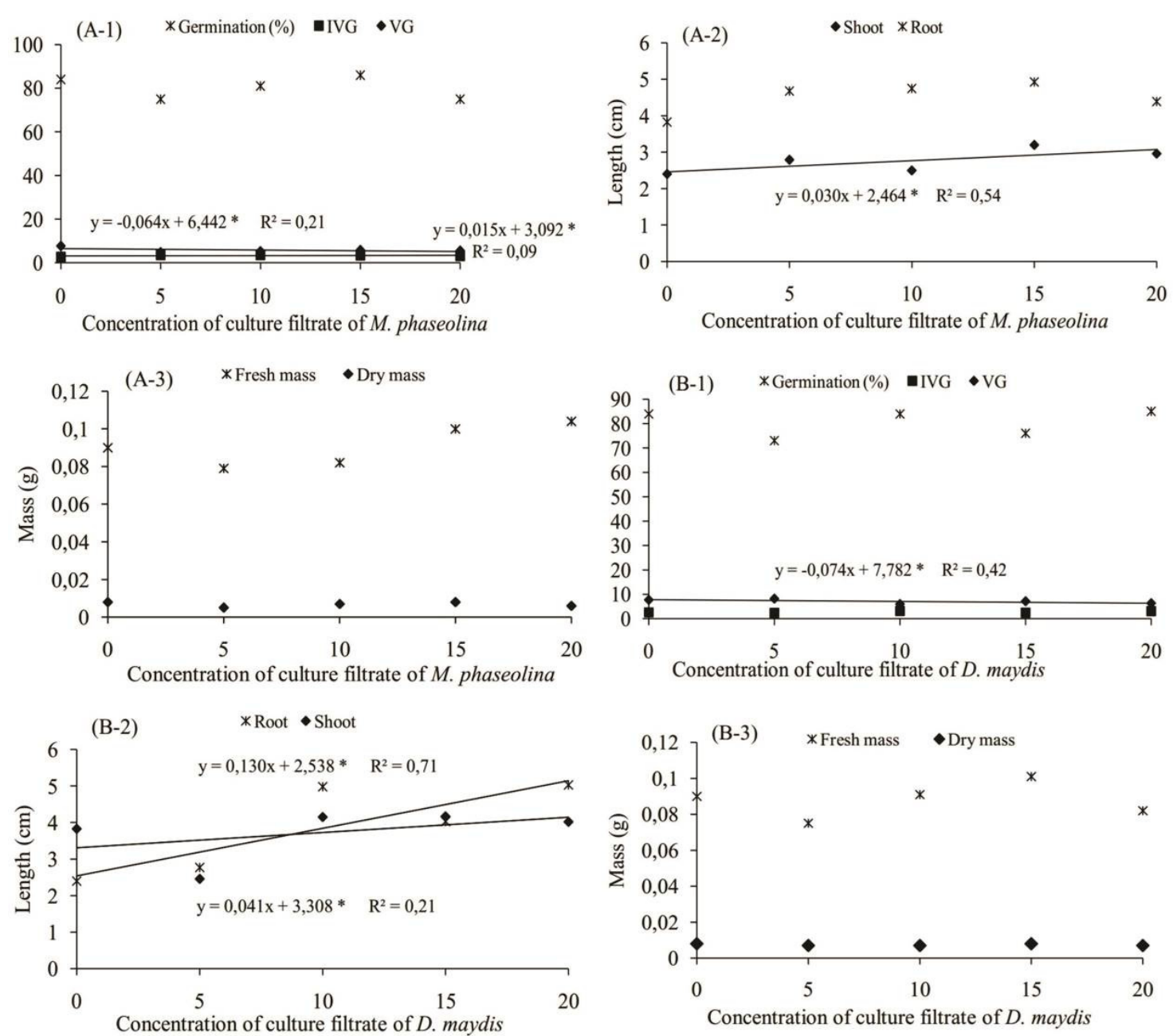

Figure 7. Germination percentage, SGI and SG (1), length (2) and mass (3) of hairy beggartticks depending on the culture filtrate produced by Macrophomina phaseolina (A) and Diplodia maydis (B) with concentrations ranging from 0 to $20 \%$. *: Significant $(\mathrm{p} \leq 0.05)$; Without curve: not significant.
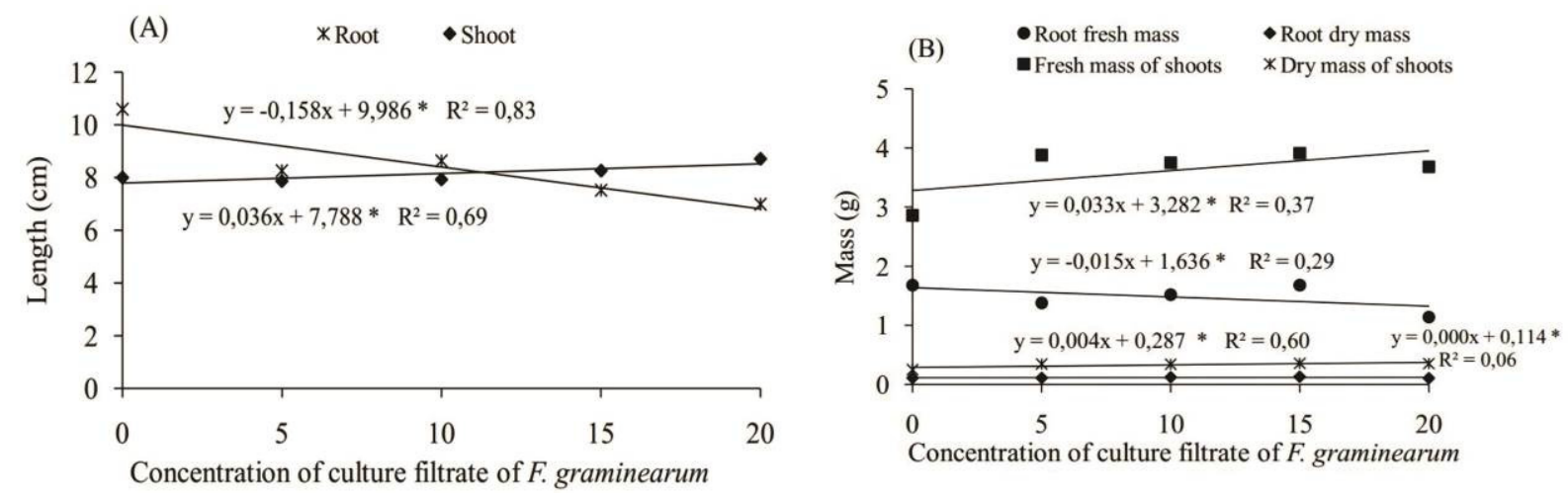

Figure 8. Length (A) and mass (B) soybean depending on the culture filtrate produced by Fusarium graminearum with concentrations ranging from 0 to $20 \%$. *: Significant $(\mathrm{p} \leq 0.05)$. 

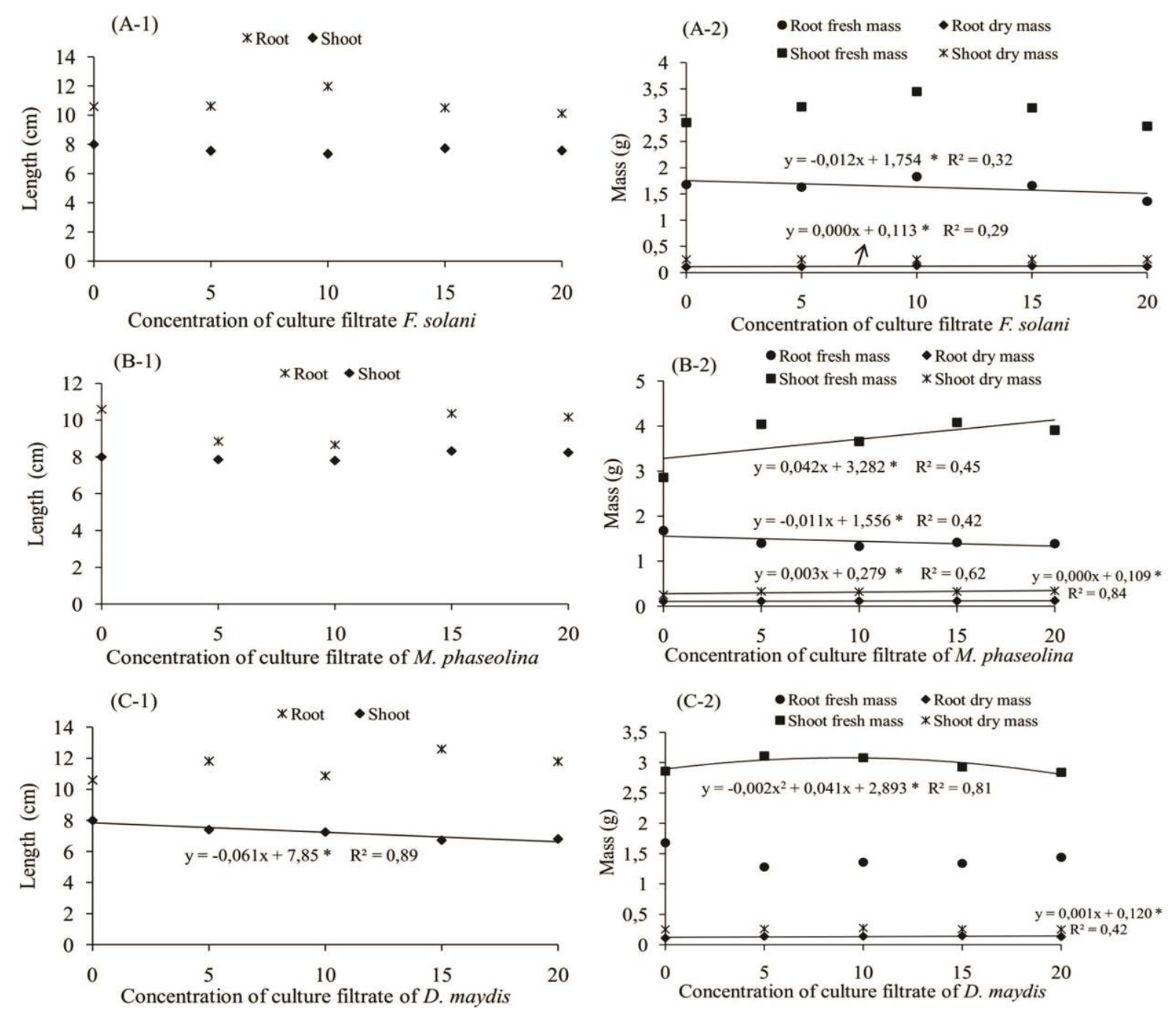

Figure 9. Length (1) and mass (2) of soybean depending on the culture filtrate produced by Fusarium solani (A), Macrophomina phaseolina, (B), Diplodia maydis, (C) at concentrations ranging from 0 to $20 \%$. *: Significant $(\mathrm{p} \leq 0.05)$; Without curve: not significant. 

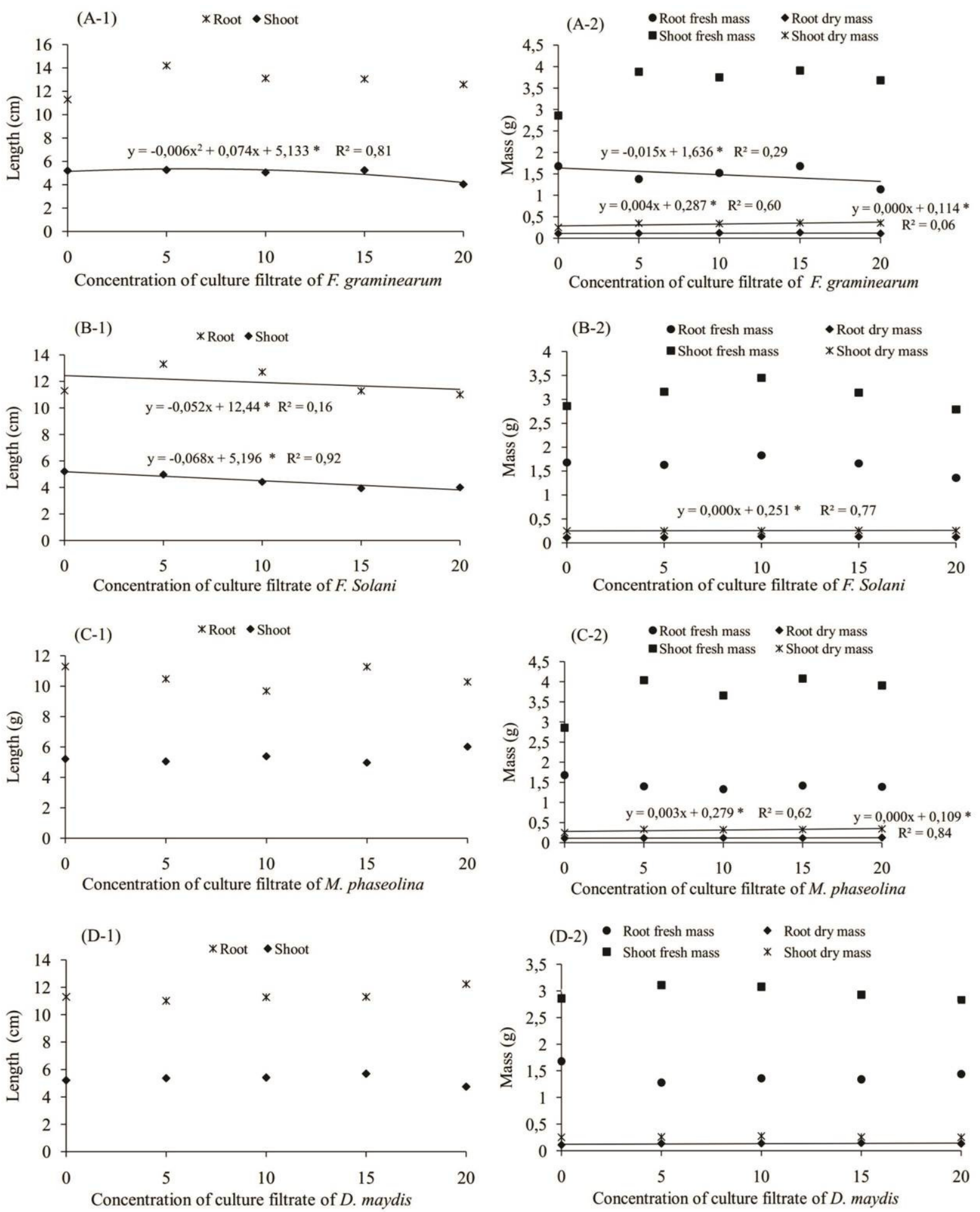

Figure 10. Length (1) and mass (2) of maize depending on the culture filtrate produced by Fusarium graminearum (A), Fusarium solani (B), Macrophomina phaseolina, (C), Diplodia maydis, (D) at concentrations ranging from 0 to $20 \%$. *: Significant ( $\mathrm{p} \leq 0.05)$; Without curve: not significant.

\section{CONCLUSIONS}

The culture filtrate of Fusarium solani reduced the speed germination index, germination speed and horseweed seedlings length; It also reduced fresh mass and seedlings growth of hairy beggarticks and shoot length and shoot's fresh mass of wild poinsettia without negatively affect on soybeans.

The filtrate from Diplodia maydis reduced the germination speed index, germination speed and horseweed seedlings length; it reduced the shoots 
growth of wild poinsettia but did not adversely affect the maize crop.

The filtrate of Macrophomina phaseolina decreased the seedlings shoot growth of wild poinsettia without negatively affecting corn.

It is suggested in this case that these filtrates may be used to control the studied as a sustainable alternative to reduce herbicides application protect the environment.

\section{ACKNOWLEDGEMENTS}

Thanks to CAPES for granting scholarship.

RESUMO: O uso de herbicidas pode ser reduzido com a utilização de controles alternativos, como emprego de fungos fitopatogênicos que produzem compostos secundários em meio de cultivo, os quais apresentam atividade fitotóxica. Objetiva-se por este trabalho caracterizar a atividade alelopática do filtrado de cultura produzido pelos fungos fitopatogênicos Fusarium solani, Macrophomina phaseolina, Fusarium graminearum e Diplodia maydis sobre a germinação de sementes e desenvolvimento de buva (Conyza canadensis), picão-preto (Bidens pilosa) e amendoim bravo (Euphorbia heterophylla), também foi testado este efeito sobre as plantas cultivadas soja e milho. O delineamento experimental foi inteiramente casualizado com vinte tratamentos (quatro filtrados de cultura, nas concentrações $0,5,10,15$ e 20\%) e quatro repetições. Os dados foram submetidos à análise de variância e regressão. Os resultados indicaram que o filtrado de cultura de Fusarium solani apresentou efeitos negativos sobre buva, picão-preto e amendoim bravo sem afetar negativamente a soja. Diplodia maydis proporcionou redução de crescimento de buva e amendoim bravo sem causar prejuízo à cultura do milho. Também, o filtrado de Macrophomina phaseolina diminuiu o crescimento de plântulas de amendoim bravo sem afetar negativamente o milho, sugerindo que esses filtrados possam ser utilizados para controle das plantas invasoras em questão como alternativa na redução da aplicação de herbicidas e proteção ao ambiente.

PALAVRAS-CHAVE: Controle alternativo. Aleloquímicos. Filtrado fúngico. Fusarium solani.

\section{REFERENCES}

AGOSTINETTO, D.; VARGAS, L. Resistência de plantas daninhas a herbicidas no Brasil. Passo Fundo: Bethier, 2009.

BANZATTO, D. A.; KRONKA, S. N. Experimentação agrícola. Jaboticabal: Funep, 1995. 247p.

BEWLEY, J. D.; BLACK, M. Seeds: physiology of development and germination. New York, Plenum Press, 1994, 361p. http://dx.doi.org/10.1007/978-1-4899-1002-8

BRASIL. Ministério da Agricultura, Pecuária e Abastecimento. Regras para análise de sementes. Secretaria de Defesa Agropecuária. Brasília : Mapa/ACS, 2009.

CARMONA, R.; VILLAS BÔAS, H. D. C. Dinâmica de sementes de Bidens pilosa no solo. Pesquisa Agropecuária Brasileira. Brasília, v. 36, n. 3, p. 457-463, 2001.

COSTA, J. A. Cultura de soja. Porto Alegre: Cinco Continentes,1996, 233 p.

DUARTE, M. L. R.; ARCHER, S. A. In vitro toxin production by Fusarium solani f. sp. piperis. Fitopatologia Brasileira. Brasília. v. 28, n. 3, p. 229-235, 2003.

EDMOND, J. B.; DRAPALA, W. J. The effects of temperature, sand and soil, and acetone on germination of okra seed. Proceedings of the American Society Horticutural Science, Alexandria, n. 71, p. 428-434, 1958.

EINHELLIG, F. A. Mechanisms and modes of actions of allelochemicals. In: PUTNAM, A. R.; TANG, C. S. (Eds.). The science of allelopathy. New York: John Willey \& Sons, 1986. p. 171- 188.

FERREIRA, A. G.; BORGHETTI, F. Germinação do básico ao aplicado. 2ª ed. Porto Alegre: Artmed, 2004.

FERREIRA, D. F. Manual do sistema Sisvar para análises estatísticas. Lavras: UFLA, 2000, 66p. 
IPARDES - Instituto Paranaense de Desenvolvimento Econômico e Social. Disponível em: $<$ http://www.ipardes.pr.gov.br>. Acesso em: 07 jun. 2011.

LAZAROTO, C. A.; FLECK, N. G.; VIDAL, R. A. Biologia e ecofisiologia de buva (Conyza bonariensis e Conyza canadensis). Ciência Rural, Santa Maria, v.38, n.3, p.852-860, 2008. http://dx.doi.org/10.1590/S010384782008000300045

MAGIERO E. C.; ASSMANN, J. M.; MARCHESE, J. A; CAPELIN, D.; PALADINI M. V.; TREZZI, M. M. Efeito alelopático de Artemisia annua L. na germinação e desenvolvimento inicial de plântulas de alface (Lactuca sativa L.) e leiteiro (Euphorbia heterophylla L.). Revista Brasileira de Plantas Medicinais, Botucatu, v.11, n.3, p.317-324, 2009.

MAGUIRE, J. D. Seeds of germination-aid selection and evaluation seedling emergence and vigor. Crop Science, Madison, v. 2, p. 176-177, 1962. http://dx.doi.org/10.2135/cropsci1962.0011183X000200020033x

MALLER; A., SILVA; H. A., REIS; B., MARQUES; R. M., MOREIRA; F. C., BONATO; C. M. Extrato aquoso e homeopatia de titonia no crescimento de amendoim bravo. XXVII Congresso Brasileiro da Ciência das Plantas Daninhas, 19 a 23 de julho de 2010a, Centro de Convenções, Ribeirão Preto - SP p. 18-21.

MARCOS- FILHO, J.; CÍCERO, S. M.; SILVA, W. R. Avaliação da qualidade fisiológica das sementes. Piracicaba: FEALQ, 1987. 230p

MORAES, W. B. C. Controle alternativo de fitopatógenos. Pesquisa Agropecuária Brasileira, Brasília, v. 27, s/n, p. 175-190, 1992.

NAKAGAWA, J. Testes de vigor baseados no desempenho das plântulas. cap 2. In: KRZYZANOWSKI, F. C.; VIEIRA, R. D.; NETO, J. B. F. (Ed) Vigor de sementes: conceitos e testes. Associação Brasileira de Tecnologia de Sementes, Comitê de vigor de sementes. Londrina: ABRATES, 1999, 246 p.

OLIVEIRA-NETO, A. M.; CONSTANTIN, J.; OLIVEIRA JR., R. S.; GUERRA, N.; DAN, H. A.; ALONSO, D. G.; BLAINSKI, E.; SANTOS, G. Estratégias de manejo de inverno e verão visando ao controle de Conyza bonariensis e Bidens pilosa. Planta Daninha, Viçosa, v. 28, n. spe, p. 1107-1116, 2010.

RIZZARDI, M. A.; VIDAL R. A.; FLECK, N. G.; AGOSTINETTO, D. Resistência de plantas aos herbicidas inibidores da acetolactato sintase. Planta Daninha, Viçosa, v. 20, n. 1, 2002.

SOUZA-FILHO, A. P. S.; DUARTE, M. L. R. Atividade alelopática do filtrado de cultura produzido por Fusarium solani. Planta Daninha, Viçosa, v. 25, n. 1, p. 227-230, 2007.

SOUZA, A. P. S. F.; RODRIGUES, R. R. A.; RODRIGUES, T. J. D. Efeito do potencial alelopático de três leguminosas forrageiras sobre três invasoras de pastagens. Pesquisa Agropecuária Brasileira, Brasília, v. 32, n. 2, 1997.

VIECELLI, C. A.; STANGARLIN J. R., KUHN, O. J.; SCHWAN-ESTRADA, K. R. F. Indução de resistência em feijoeiro por filtrado de cultura de Pycnoporus sanguineus contra Pseudocercospora griseola. Tropical Plant Pathology. Brasília, v. 34, n. 2, 2009.

WALLER, G. R.; FEUG, M. C.; FUJII, Y. Biochemical analysis of allelopathic compounds: plants, microorganisms, and soil secondary metabolites. In: INDERJIT; DAKSHINI, K. M. M.; FOY, C. L. (Eds.) Principles and practices in plant ecology. Boca Raton, CRC Press. p. 75-98, 1999.

WEIH, M.; DIDON, U. M. E.; RONNBERG-WASTLJUNG A. C.; BJORKMAN, C. Integrated agricultural research and crop breeding: Allelopathic weed control in cereals and long-term productivity in perennial biomass crops. Agricultural Systems, Wageningen, v. 97, n. 3, p. 99-107, 2008.

http://dx.doi.org/10.1016/j.agsy.2008.02.009 